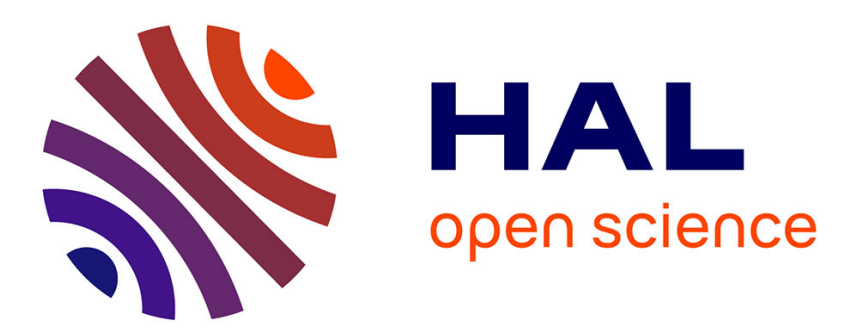

\title{
Comparison of solid and liquid-phase bioassays using ecoscores to assess contaminated soils
}

Christine Lors, Jean-François Ponge, Maite Martínez Aldaya, Denis Damidot

\section{To cite this version:}

Christine Lors, Jean-François Ponge, Maite Martínez Aldaya, Denis Damidot. Comparison of solid and liquid-phase bioassays using ecoscores to assess contaminated soils. Environmental Pollution, 2011, 159 (10), pp.2974-2981. 10.1016/j.envpol.2011.04.028 . hal-00618446

\section{HAL Id: hal-00618446 \\ https://hal.science/hal-00618446}

Submitted on 1 Sep 2011

HAL is a multi-disciplinary open access archive for the deposit and dissemination of scientific research documents, whether they are published or not. The documents may come from teaching and research institutions in France or abroad, or from public or private research centers.
L'archive ouverte pluridisciplinaire HAL, est destinée au dépôt et à la diffusion de documents scientifiques de niveau recherche, publiés ou non, émanant des établissements d'enseignement et de recherche français ou étrangers, des laboratoires publics ou privés. 
1 Comparison of solid and liquid-phase bioassays using ecoscores to assess

2 contaminated soils

3

4 Christine Lors ${ }^{\mathrm{a}, \mathrm{b}, \mathrm{c}}$, Jean-François Ponge ${ }^{\mathrm{d} *}$, Maite Martínez Aldaya ${ }^{\mathrm{d}}$, Denis Damidot ${ }^{\mathrm{a}, \mathrm{b}}$

a'Université Lille Nord de France, 1 bis rue Georges Lefèvre, 59044 Lille Cedex, France

7

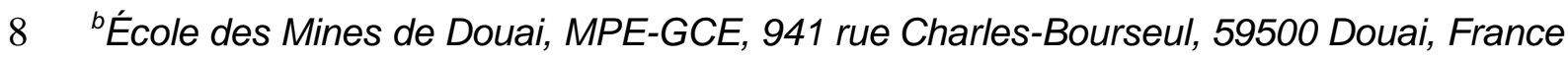

$10{ }^{\circ}$ Centre National de Recherche sur les Sites et Sols Pollués, 930 Boulevard Lahure, BP 11 537, 59505 Douai Cedex, France

'Muséum National d'Histoire Naturelle, CNRS UMR 7179, 4 Avenue du Petit-Château,

1491800 Brunoy, France

15

16 Abstract

17

18

Bioassays on aqueous and solid phases of contaminated soils were compared,

19 belonging to a wide array of trophic and response levels and using ecoscores for

20 evaluating ecotoxicological and genotoxicological endpoints. The method was applied to

\footnotetext{
* Corresponding author. Tel. +33 6 78930133, fax +33 1 60465719, e-mail: ponge@mnhn.fr
} 
1 four coke factory soils contaminated mainly with PAHs, but also to a lesser extent by

2 heavy metals and cyanides. Aquatic bioassays do not differ from terrestrial bioassays

3 when scaling soils according to toxicity but they are complementary from the viewpoint of

4 ecological relevance. Both aquatic and terrestrial endpoints are strongly correlated with

5 concentrations of 3-ring PAHs. This evaluation procedure allows us to propose a cost-

6 effective battery which embraces a wide array of test organisms and response levels: it

7 includes two rapid bio-assays (Microtox ${ }^{\circledR}$ and springtail avoidance), a micronucleus test

8 and three bio-assays of a longer duration (algal growth, lettuce germination and springtail

9 reproduction). This battery can be recommended for a cost-effective assessment of 10 polluted/remediated soils.

11

\section{Capsule}

Aqueous and solid phases of contaminated soils give similar results in terms of toxicity but are complementary for the evaluation of environmental hazards by ecoscores.

Keywords: PAHs; Heavy metals; Contaminated soils; Solid-phase bioassays; Liquidphase bioassays; Toxicity; Ecoscores

\section{Introduction}

Some industrial activities can generate hazardous chemicals that may contaminate

23 soils located in the vicinity of plants. Soil pollutants include polycyclic aromatic 
1 hydrocarbons (PAHs) and heavy metals, which represent an important environmental

2 concern, due to potential adverse ecological and toxicological effects (Bispo et al., 1999;

3 Boularbah et al., 2006). Hazard assessments of polluted soils are usually performed by a

4 chemical approach. However, chemical data do not give an exhaustive list of all the

5 contaminants contributing to toxicity. Indeed, soil pollutant concentrations do not provide

6 any information on (i) biological effects of toxic compounds, (ii) synergetic or antagonistic

7 interactions between pollutants, and (iii) bioavailability of pollutants (Maxam et al., 2000;

8 Juvonen et al., 2000; Vasseur et al., 2008). As a consequence, pollutants, even when

9 present at weak or undetectable concentrations, can generate negative effects on the

10 activities of organisms. In order to estimate the actual risk of contaminants, chemical

11 analyses must be complemented with biological and toxicological assays, including

12 organisms belonging to a wide array of trophic levels, and living both in solid and aqueous

13 phases (Hoffman et al., 2002), avoidance responses of motile organisms being

14 considered as an 'early warning signal', to be added to current environmental risk assessment (Hellou, 2011).

Solid-phase and liquid-phase bio-assays on soils have been compared in order to assess whether they were complementary, i.e. by addressing different kinds of ecotoxicity, or redundant, i.e. by classifying soils in the same order of ecotoxicity (Juvonen et al., 2000; Pandard et al., 2006; Eom et al., 2007; Leitgib et al., 2007; Manzo et al., 2008). There were clear discrepancies according to the type of soils which were studied and to the type of pollutant to which each bio-assay was sensitive. It thus appears that there is a need for a method allowing bulk comparisons between soils, between phases of the same soil and between response levels of organisms belonging to widely diverging trophic groups such as plants, protists and terrestrial and aquatic metazoa.

The present work complements a previous study by Lors et al. (2010a) who assessed the toxicity of several contaminated soils issued from a former coal tar distillery 
1 by using chemical and ecotoxicological analyses. Studied soils differed by their PAH

2 concentration and by the occurrence or not of a mixed pollution of heavy metals and/or

3 cyanides. The toxicity of these soils was determined with solid-phase bioassays based on

4 the germination and growth of the lettuce Lactuca sativa, the survival of the earthworm

5 Eisenia fetida and the avoidance behaviour and the reproduction of the springtail $F$.

6 candida. Ecoscores, a numerical method rescaling results from methods using a variety of

7 concentration ranges of polluted soils, was used to facilitate comparisons between

8 different endpoints, and between soils. This study concluded to the higher sensitivity of

9 behavioural (avoidance) tests compared to toxicological bio-assays based on growth and

10 reproduction, and to a clear allocation of organism responses to the concentration in 3-

11 ring $\mathrm{PAHs}$.

In the present paper, the toxicity of water extracts obtained from the same soils

13 (Lors et al., 2010a) was evaluated on organisms representing different trophic levels. The acute effects of soil water extracts were assessed by Microtox ${ }^{\circledR}$ and Daphnia magna tests,

15 and their chronic effects by the growth inhibition of Pseudokirchneriella subcapitata and

16 Brachionus calyciflorus populations. The genotoxicity of aqueous phases was analyzed

17 through the micronucleus test applied on the mouse lymphoma L5178Y.

We will ask whether ecoscores, a numerical method rescaling results from

19 methods using a variety of concentration ranges of polluted soils (Lors et al., 2010a), can

20 be used to (1) facilitate comparisons between endpoints of aqueous and solid phase bio-

21 assays, and (2) suggest a restricted battery of tests to perform a cost-effective risk 22 assessment of polluted soils. 
1

\subsection{Soil samples}

Soils were provided from three industrial sites located in the North of France. Soil 1 and Soil 2 came from two former industrial sites where coal distillation took place from 1925 to 1971 and from 1925 to 1973 , respectively. These soils were fairly polluted with a mixture of PAHs, cyanides and heavy metals (Lors et al., 2010a). Soil 2 was bioremediated from October 1995 to June 1997 by landfarming: despite biotreatment it still contained a high amount of PAHs, similar to that of Soil 3. Soil 3, came from an industrial site where coal tar distillation took place from 1923 to 1987 , it was only contaminated with PAHs. Soil 3 was treated by a windrow process from August 2003 to February 2004 (Lors et al., 2010a). The biotreatment process was detailed in Lors et al. (2010b). Soil 3T, which represented the soil after biotreatment, contained the lowest PAHconcentration. Data on soil texture, pH, total C, N, P were provided in Lors et al. (2010b).

Twenty to $30 \mathrm{~kg}$ of Soil 1 and Soil 2 were sampled from Site 1 and Site 2, respectively, between 1 and $2 \mathrm{~m}$ of depth in the non-waterlogged zone and in 10 randomly chosen plots. Sampling of Soil 1 and Soil 2 took place in February 2002. Soil samples were then mechanically homogenized and sieved at $4 \mathrm{~mm}$. Soil 3 and Soil $3 T$ were also sieved at $4 \mathrm{~mm}$ after a specific sampling procedure described in Lors et al. (2010b). They were sampled in August 2003 and February 2004, respectively.

Unpolluted soils were also sampled in uncontaminated areas of the three studied sites. These soils were used as controls in the avoidance test and as a matrix of dilution in terrestrial ecotoxicity bioassays. Previous chemical and ecotoxicological analyses were performed on control soils, which did not reveal any ecotoxicity. 
To realize liquid-phase bioassays on soil samples, a first step of extraction by

3 water was necessary. Soil water extraction was carried out according to ISO (2007)

4 without any preliminary filtration. Soil water extraction was carried out with a liquid/solid 5 ratio of $10 / 1$ ( $170 \mathrm{~g}$ of soil in $1.7 \mathrm{I}$ of distilled water) at $20^{\circ} \mathrm{C}$ in 2 I glass bottles for $24 \mathrm{~h}$ at a

6 stirring rate of $60 \mathrm{rpm}$. After decantation for $15 \mathrm{~min}$, the soil suspension phase was

7 centrifuged at $2,000 \mathrm{~g}$ during $30 \mathrm{~min}$ and stored at $4^{\circ} \mathrm{C}$ until ecotoxicological analysis.

9 2.3. Chemical analyses of soil samples and water extracts

Metals, PAHs (list of 16 US-EPA PAHs) and cyanides were measured on the tested soils and on water extracts of all soils. These chemical analyses were done in 13 triplicate.

14

Metals (As, Cd, Co, Cr, Cu, Ni, Pb, Zn) were dosed by Inductive Coupled Plasma Atomic Emission Spectrometry (ICP-AES) in a 138 Ultrace Jobin Yvon ${ }^{\circledR}$ analyser according to ISO (2008b). For the soil samples, a hot digestion of the solid phase was carried out with hydrofluoric and perchloric acids, according to ISO (2001).

Concentrations of the 16 PAHs of the US-EPA list (Verschueren, 2001) were dosed in soil and and water extracts according to ISO (1998b). However, PAH concentration in water extracts did not include acenaphtylene. The separation of PAHs from water extracts was conducted with dichloromethane. The extraction of PAHs from soil samples was carried out with the solvent extractor system Dionex ${ }^{\circledR}$ ASE 200 (Dionex Corporation $^{\circledR}$, Sunnyvale, CA), allowing a solid/liquid extraction with a solvent mixture (dichloromethane/acetone ratio $1 / 1 \mathrm{v} / \mathrm{v}$ ) for $15 \mathrm{~min}$ at $100^{\circ} \mathrm{C}$ and $13.8 \times 10^{6} \mathrm{~Pa}$. The 
1 solvent was evaporated under an air stream to nearly dryness and the samples were

2 diluted with acetonitrile before $0.45 \mu \mathrm{m}$ filtration. The concentrations of the $16 \mathrm{PAHs}$ were

3 dosed in the extracts by High Performance Liquid Chromatography (Waters ${ }^{\circledR}$ HPLC 2690,

4 Milford, MS), coupled to a UV photodiode array detector (Waters ${ }^{\circledR}$ 996). PAHs were

5 separated in a column (Supelco ${ }^{\circledR} \mathrm{C} 18$ reverse phase, length $250 \mathrm{~mm}$, internal diameter

$62.1 \mathrm{~m}$ ) using a gradient of acetonitrile/water solvent. PAH analyses were carried out in soil

7 water extracts by HPLC (Waters ${ }^{\circledR} 2690$, Milford, MS) coupled to a fluorescence detector.

8 The ratio between $\mathrm{PAH}$ concentration in water extract and $\mathrm{PAH}$ concentration in soil

9 allowed to determine the PAH water extraction capacity of the studied soils.

11 (2002), respectively.

Bioassays were performed to assess the direct toxicity of soils and soil water extracts to terrestrial and aquatic organisms, respectively. A description of the bioassays, comprising test procedure, type of toxicity measured, selected endpoints, duration and tested organisms, was given in Table 1. The set of bioassays included bioassays of acute, chronic and genotoxicity effects, using organisms which were representative of a variety of trophic levels.

Toxicity results were the responses of test organisms according to soils or water extracts in test media $(\%, w / w)$. The results were calculated as concentrations producing no significant effect (NOEC), percent inhibition at the highest concentration of the tested sample or as concentrations decreasing the measured endpoint by $10 \%, 20 \%$ and $50 \%$ $\left[E(L) C_{10}, E(L) C_{20}\right.$ and $E(L) C_{50}$, respectively] compared to controls. 
2.4.1. Terrestrial toxicity tests

3

4

The toxicity of soils was evaluated with the same bioassays than those used by Lors et al. (2010a). Acute toxicity bioassays included phytotoxicity tests on Lactuca sativa (ISO, 2005) and the survival test on Eisenia fetida (ISO, 1993). Chronic effects were evaluated on springtail (Folsomia candida) reproduction according to ISO (1999) modified by Martínez Aldaya et al. (2006). An avoidance test was conducted on Folsomia candida according to Martínez Aldaya et al. (2006) and Lors et al. (2006). Detailed procedures of these bioassays were described by Lors et al. (2010a). The pH of all soils was compatible with requirements of test organisms, varying from 7.8 for Soil 2 to 8.3 for Soil 3T (Lors et al., 2010a).

\subsubsection{Aquatic (geno)toxicity tests}

(1)

All aquatic bioassays were performed within $24 \mathrm{~h}$ after preparation.

The toxicity of water extracts to aquatic organisms was assessed through both acute and chronic effects. Acute toxicity tests were performed by measuring the inhibition of bioluminescence of the bacterium Vibrio fischeri according to ISO (1998a) and the immobilization of the crustacean Daphnia magna according to ISO (1996). Chronic toxicity was evaluated on growth of the fresh water alga Pseudokirchneriella subcapitata according to ISO (2004) and the planktonic rotifer Brachionus calyciflorus according to ISO (2008a). The $\mathrm{pH}$ of the water extracts was close to 8 for all soils studied, which is compatible with the validity domain of toxicity tests performed in the present study. 
The in vitro micronucleus assay was performed according the procedure described

2 by Nesslany and Marzin (1999). This micro-method used mouse lymphoma cells L5178Y.

3 The micronucleus assay was performed with and without S9 metabolic activation using

4 the $9000 \mathrm{~g}$ cell supernatant from livers of Aroclor 1254-treated rats.

$6 \quad$ 2.4.3. Data analysis

Toxic effects were calculated as percentages of inhibition at a given concentration

9 or as $L E_{C x}$ values. Percent inhibition was determined with respect to the control soil. $L_{E_{C x}}$ values were calculated following adjustment of data to a log-probit logistic model

11 (Litchfield and Wilcoxon, 1949). NOEC was the highest concentration tested that did not significantly differ from control at type I error $(\alpha)$ of $5 \%$. LOEC was not used and was

13 replaced by $\mathrm{EC}_{10}$ or $\mathrm{LC}_{10}$. Toxicity values were also expressed into Toxic Units (TU), using

14 the formula TU $=100 / E C(\text { or LC) })_{50}$.

Ecoscores were calculated from five ecotoxicological parameters, $E(L) C_{50}, E(L) C_{20}$,

$16 E(L) C_{10}, N O E C$, and \% inhibition, by giving to each endpoint value a score between 0 and

173 as a function of its intensity, according to the scales defined by Lors et al. (2010a):

- for $E(L) C_{50}, E(L) C_{20}, E(L) C_{10}$, and NOEC

$\circ \quad 0=$ no effect $(x>100)$

○ 1 = weak effect $(50<x \leq 100)$

○ 2 = medium effect $(20<x \leq 50)$

○ 3 = strong effect $(x \leq 20)$

- $\quad$ for $\%$ inhibition

$0 \quad 0=$ no effect $(x \leq 5)$

○ $1=$ weak effect $(5<x \leq 20)$ 
$\circ \quad 2$ = medium effect $(20<x \leq 60)$

- $3=$ strong effect $(x>60)$

The five ecoscores were summed up and the total was rescaled to 100 for maximum intensity of the five endpoints.

Correlation analysis, using the Pearson product-moment correlation coefficient (r), was used to explore possible linear relationships between physicochemical parameters and toxicity endpoints. The probability $(\mathrm{P})$ of reaching values higher than the observed value with the null hypothesis (absence of correlation) was also given, as well as the coefficient of determination $\left(R^{2}=r^{2}\right)$ of linear regression, which expresses the part of the total variance of a parameter which is explained by a linear relationship with another parameter.

All calculations were done with the statistical software XSTAT $^{\circledR}$ (Addinsoft $^{\circledR}$, Paris, France), using Excel ${ }^{\circledR}$ (Microsoft Corporation ${ }^{\circledR}$, Redmond, WA).

\section{Results}

\subsection{Chemical analyses of soils}

Concentrations of 16 PAHs, cyanides and metals of studied soils (average values of three replicate measures) were reported in Table 2, together with geochemical background values and Predicted No-Effect Concentrations (PNEC) for the sake of comparison. All studied soils exhibited PAH concentrations which were far above PNEC values, except for acenaphthylene in Soil 3 after bio-treatment (Soil 3T). 
1 contained low amounts of PAHs, cyanides and heavy metals. Soil 2 was highly

2 contaminated with PAHs, despite landfarming treatment and was contaminated with PAHs

3 of higher molecular weight than Soil 1. It was also contaminated with heavy metals, in

4 particularly $\mathrm{Zn}, \mathrm{Pb}, \mathrm{Cu}$ and $\mathrm{Cd}$, contents of which were 7 to 12 times the geochemical

5 background and all above PNEC values. Cyanides were also in considerable amount in

6 Soil 2.

Contrarily to Soil 1 and Soil 2 , Soil 3 was mainly contaminated with organic compounds, and particularly with PAHs which amounted to the same level as Soil 2.

9 Despite similar global amounts of PAHs in Soils 2 and 3, their distribution was different,

10 Soil 3 containing mainly 2-, 3- and 4-ring PAHs. Conversely, heavy metals and cyanides

11 were not important contaminants of Soil 3, with concentrations close to the geochemical

12 background, and equal or below PNEC values. It should be noted that the geochemical

13 background for $\mathrm{Ni}$ in the study region was somewhat above PNEC values. Soil 3T, which

14 corresponded to Soil 3 after six months of windrow biotreatment, contained a much lower PAH concentration (nearly 10 times less) than Soil 3 . In particular biotreatment led to a

16 strong degradation of 2-, 3- and 4-ring PAHs. As Soil 3 contained low concentrations of 17 heavy metals, no evolution of their content was observed after biotreatment. $\mathrm{kg}^{-1}$ dry soil), metals (around geochemical background) and cyanides (content below 0.1 to $0.2 \mathrm{mg} \mathrm{kg}^{-1}$ dry soil), like already shown by Lors et al. (2010b).

The chemical characteristics of water extracts of studied soils were presented in

Table 3. Metals and cyanides (data not shown) were at concentrations lower than 
1 detection limits, except for $\mathrm{Cu}$ and $\mathrm{Pb}$ in Water extract $2\left(0.06\right.$ and $0.04 \mu \mathrm{g} \mathrm{\textrm {I } ^ { - 1 }}$, 2 respectively).

Water extract 1 contained a very low PAH content (although above PNEC values), 3- and 4-ring PAHs being the most easily leached (Fig. 1). Among them, the major compounds in solution were anthracene and pyrene (Table 3). Their occurrence in Water extract 1 was related to their concentration in Soil 1, where 3- and 4-ring PAHs were the most represented among the 16 PAHs of the US-EPA list (Table 2).

Water extract 2 was distinguished from Water extract 1 by higher amounts of PAHs, the water extraction capacity of Soil 2 being three times that of Soil 1 (Table 4). Moreover, 5- and 6-ring PAHs occurred in major proportions, (Fig. 1), and reached higher concentrations than in Water extract 1 (Table 3).

Water extract 3 was highly contaminated with PAHs, the soil water extraction capacity of Soil 3 (ratio water extract/soil in PAH concentration) being near ten times that of Soil 2 (Table 4). All concentration values of individual PAHs in Water extract 3 were well above corresponding PNEC values. Water extract 3 mainly contained 3-ring PAHs (Fig. 1). Their high concentration in solution was linked to their high amount in Soil 3 (Table 2). Four-ring PAHs were also present but in a smaller proportion (Fig. 1). Five- and 6-ring PAHs were in weaker amounts (Fig. 1). Naphthalene, which was in a high amount in Soil 3, was surprisingly present at a small concentration $\left(0.2 \mu \mathrm{g} \mathrm{I}^{-1}\right)$ in the corresponding water extract. This was probably due to its volatilization during water extraction, given its high vapour tensile strength $(37 \mathrm{~Pa})$. The $\Sigma$-PAH concentration of Water extract $3 \mathrm{~T}$ was clearly weaker than that of Water extract 3 . The biotreatment of Soil 3 thus allowed a considerable reduction (84\%) of PAHs extracted by water, which mainly concerned 3-ring PAHs (99\%). Three-ring PAHs were present in a very small proportion, not exceeding 5\%. Five- and 6-ring PAH concentrations measured in Water extract 3T were double those of Water extract 3 (Table 3), contrary to what was observed in the corresponding soil 
1 matrices, for which a reduction in their content was detected (Table 2).

\subsection{Toxicological analyses of water extracts}

4

Water extract 1 did not exhibit any genotoxicity, as estimated by the micronucleus test (Table 5). Acute and chronic toxicity tests displayed contrasting results according to methods in use. Among acute toxicity tests, the Microtox ${ }^{\circledR}$ test was more sensitive than the Daphnia mobility test, as shown by ecoscores. Conversely, among chronic toxicity tests, the algal growth test was more sensitive than the rotifer test. On the basis of Microtox ${ }^{\circledR}$ and algal growth tests, Water extract 1 presented moderate acute and chronic toxicities as shown by $\mathrm{EC}_{10}$ and \% of inhibition compared to control.

Water extract 2 did not show any genotoxicity as estimated by the micronucleus test (Table 6). Moreover, it did not exhibit any acute toxicity with respect to Vibrio fischeri $\left(\right.$ Microtox $^{\circledR}$ ) and Daphnia magna (micro-crustacean) tests. Conversely, algal and rotifer tests revealed chronic toxicity, according to ecoscores. The chronic toxicity of Water extract 2 was higher than that of Water extract 1 . As observed for Water extract 1 , the algal growth test was more sensitive than the rotifer test.

Water extract 3 displayed a pronounced acute toxicity whatever the test used (Table 7). Indeed, this water extract showed a significant effect on the inhibition of the

20 luminescence of Vibrio fischeri and the mobility of Daphnia magna. Moreover, it presented 21 a high chronic toxicity and a high genotoxicity (only without S9).

Water extract 3T showed that after six months of biotreatment, acute toxicity 23 decreased to a great extent, as ascertained by Microtox ${ }^{\circledR}$ and Daphnia mobility tests, while 24 chronic toxicity displayed contrasting results according to the test used (Table 8). The 
1 genotoxicity of Water extract 3T was nil according to the micronucleus test.

\subsection{Comparison of liquid and solid bio-assays by ecoscores}

4

The two acute toxicity tests on soil water extracts (Microtox ${ }^{\circledR}$ and Daphnia mobility) did not exhibit the same sensitivity. While both of them revealed a pronounced toxicity in the water extract of Soil 3 and did not detect any acute toxicity in the water extract of Soil 2 (Table 9), only Microtox ${ }^{\circledR}$ revealed a toxicity in the water extracts of Soils 1 and 3T (despite biotreatment for the latter), pointing to a better sensitivity of Microtox ${ }^{\circledR}$ when compared to Daphnia mobility.

Except for Soil 3, where the two chronic toxicity tests revealed a pronounced toxicity of its aqueous phase (Table 9), the algal growth test was more sensitive than the rotifer test. In particular the former was the only test able to reveal a chronic toxicity in the aqueous phase of Soil 1 and Soil 3T.

The micronucleus test did not show any genotoxicity in the aqueous phase of studied soils (Table 9), to the exception of the most contaminated Soil 3.

Results of solid phase bio-assays have been already detailed in Lors et al. (2010a). In short, the behavioural test (avoidance by Folsomia) showed a better sensitivity than ecotoxicity tests. Nevertheless, inhibition of lettuce (Lactuca) germination and springtail (Folsomia) population growth tests were more sensitive than earthworm (Eisenia) mortality and lettuce growth inhibition tests. Moreover, the springtail reproduction test was the only bio-assay which showed some remaining toxicity in Soil 3 after bio-

23 treatment (Soil 3T). These results seem to show a risk of long-term toxicity of Soil 3T.

24 However, this response must be confirmed by other chronic bioassays. 
Mean ecoscores for liquid (5 bio-assays) and solid (5 bio-assays) phases allowed

2 to compare the sensitivity of both groups of tests (Fig. 2). Both phases were highly 3 correlated $(r=0.996, P=0.004)$, indicating that water extracts reflected fairly well the

4 toxicity of solid phases, at least within the limits of selected bio-assays. However, the use

5 of a restricted number of soils (four in the present study) does not allow concluding

6 definitely to the existence (or not) of strong relationships between liquid and solid phase

7 bio-assays. In the same way, when pooling ecoscores, the four soils were classified in the

8 same increasing order of toxicity for liquid phase bioassays than for solid phase

9 bioassays: Soil/Water extract $3 \mathrm{~T}<$ Soil/Water extract $2<$ Soil/Water extract $1<<$

10 Soil/Water extract 3. However, ecoscores calculated on solid-phase bioassays were

11 always somewhat higher (mean ratio 1.2) than those calculated on liquid-phase

12 bioassays, indicating a better sensitivity to contamination. In addition, bioassays on both

13 phases showed that the best correlation of mean ecoscores (pooled over five bioassays)

14 was obtained with the concentration of 3-ring PAHs: $r=0.954$ and 0.957 , with $P=0.046$

15 and 0.043 for solid and liquid phases, respectively.

16 No significant relationship was observed with heavy metals, which was coherent

17 with their weak amount and their poor solubility in the studied soils.

\section{Discussion}

The use of water extracts of soil samples for the assessment of environmental hazards of water-mobilised soil pollutants has been critically examined (Leitgib et al.,

23 2007; Manzo et al., 2008; Pablos et al., 2009). Toxicity endpoints on aquatic organisms

24 need a previous soil water extraction which does not mimic exactly what happens when a soil matrix contaminated with PAHs is in permanent exchange with soil solution, in 
1 particular when organic or inorganic contaminants are adsorbed on clay surfaces

2 (Degryse et al., 2009; Changchaivong and Khaodhiar, 2009) and microbial biofilms (Wicke

3 et al., 2007). Lixiviation tests are cheap and of a short duration, and the water extraction

4 process does not allow exchanges between matrix and solution to reach equilibrium, even

5 after $24 \mathrm{~h}$ (Gamst et al., 2007), and thus they may underestimate PAH concentrations in

6 the soil solution according to solubility (Hitchcock and Smith, 1998). Bioassays applied to

7 soil water extracts allow predicting groundwater hazards of contaminants, but are poorly

8 predictive when the whole soil is considered as an environmental element (Leitgib et al.,

9 2007). In the present study we showed on a restricted array of industrial soils mainly contaminated by PAHs that aquatic bio-assays give the same information (although at a lower level of sensitivity) as solid phase bio-assays in the evaluation of bulk soil toxicity.

12 The sensitivity of aquatic bio-assays was expressed by mean of ecoscores, a method 13 applied by Lors et al. (2010a) on the same soils but to terrestrial organisms only. Both 14 phases consider different kinds of organisms, not necessarily living in the same microenvironment (Vannier, 1987) and endpoints are calculated on quite different scales, but the use of ecoscores in place of original endpoint values facilitates comparisons to be made between them. The observed convergence of aquatic and terrestrial bio-assays has been already mentioned in the evaluation of $\mathrm{PAH}$ contamination, although not purposely tested, by several authors (Juvonen et al., 2000; Pandard et al., 2006; Eom et al., 2007; Manzo et al., 2008). It could be explained by common metabolic routes for PAHs once contaminants are at the inside of an organism, whether ingested with soil or directly absorbed from the outside, in particular for low molecular weight PAHs (Leaner and Mason, 2002; Van de Wiele et al., 2004). We also showed that both aquatic and terrestrial endpoints were strongly correlated with the concentration of 3-ring PAHs, which are common to aquatic and solid phases, and cross easily cell membranes (Kang et al., 2010).

The lower sensitivity of liquid-phase bioassays can be explained by (I) the time 
1 needed for equilibrium to be reached between the soil matrix and the water extract

2 suspension, more especially for $\mathrm{PAHs}$ with a high molecular weight, and (ii) the lower

3 concentration of PAHs in the water extracts compared to the bulk soil (Table 4). It should

4 be noticed that the studied soils are old coke factory sites, where industrial activities

5 ceased for more than 20 years, resulting in lower exchanges between liquid and solid

6 phases due to physically- and microbially-enhanced immobilisation of PAHs and heavy

7 metals during ageing of the soil matrix (Sayer et al., 1999; Eom et al., 2007; Zhao et al.,

8 2009). This may explain the low level of liquid-phase ecotoxicity observed in these soils,

9 when compared to solid phases, and reinforces the usefulness of an ecotoxicological

10 approach incorporating the whole soil (Vasseur et al., 2008).

We showed that ( $I$ ) among aquatic-phase (indirect) toxicity bio-assays the Microtox $^{\circledR}$ test (inhibition of bioluminescence of $V$. fischeri) and the algal 13 (Pseudokirchneriella) growth test were more sensitive than the Daphnia mobility and the rotifer (Brachionus) growth tests, (ii) among solid-phase (direct) toxicity bio-assays the inhibition of lettuce (Lactuca) germination, the springtail (Folsomia) population growth and avoidance tests were more sensitive than earthworm (Eisenia) mortality and lettuce 17 growth inhibition tests. All these bio-assays exhibited ecoscores higher than 40 (Table 9). To these ecotoxicity tests should be added the micronucleus test, which detected with a high ecoscore (80) the genotoxicity of the aqueous phase of Soil 3 (Table 9). That genotoxicity was detected by the micronucleus test in the absence of S9 activator indicated direct genotoxicity. This may allow us to suggest a reduced test battery of six tests (Table 9) including two rapid bio-assays (Microtox ${ }^{\circledR}$ and springtail avoidance, a few minutes each) and three bio-assays of a longer duration (algal growth, lettuce germination and springtail reproduction, a few days to a few weeks each). Our method of selection, based on ecoscores, differed from that of Pandard et al. (2006), who used a multivariate analytical method, Principal Components Analysis followed by cluster analysis of a data 
1 not include springtail tests, the classification of soils by a reduced battery of tests was

2 compared to that obtained with the complete set of bioassays. Both methods selected

3 Microtox $^{\circledR}$ and lettuce germination for the restricted battery, but they differed mainly in the

4 inclusion of springtail avoidance and reproduction tests in our complete battery: these

5 tests proved to be particularly sensitive and were kept in our restricted battery. Compared

6 to multivariate analyses, the use of ecoscores, each endpoint being evaluated separately

7 from the others (Lors et al., 2010a) allows addition or deletion of a test (or of a sample)

8 without interfering with the evaluation of other endpoints (or samples).

\section{Conclusion}

In the present study, environmental toxicity methods were compared in a restricted array of four coke factory soils contaminated mainly with PAHs at varying concentrations (all above expected risk) and to a lesser extent with heavy metals and cyanides. Toxicity was evaluated both on the whole soil and on the soil extract. Solid-phase bio-assays were based on the germination and growth of the lettuce Lactuca sativa, the survival of the earthworm Eisenia fetida and the avoidance behaviour and the reproduction of the springtail Folsomia candida. The toxicity of water extracts of soils was determined by

19 acute Microtox ${ }^{\circledR}$ and Daphnia magna tests, chronic Pseudokirchneriella subcapitata and

20 Brachionus calyciflorus tests and genotoxic micronucleus test on the mouse lymphoma 21 L5178Y.

On the basis of the ecoscore method of evaluation of test performance, we 23 showed that liquid-phase bio-assays allowed classing the four contaminated soils in the 24 same order than soil-phase bio-assays, although at a somewhat lower level of sensitivity $25(\times 0.8)$. 
In addition, both solid- and liquid-phase bio-assays were strongly correlated with

2 concentration of 3 -ring PAHs. According to our results, and within the limits of our

3 restricted study which did not include a variety of pollution sources, a restricted battery of

4 six bio-assays can be proposed, including both solid and liquid phases and addressing

5 acute as well as chronic toxicity and genotoxicity: two rapid bio-assays (Microtox ${ }^{\circledR}$ and

6 springtail avoidance, a few minutes each), a one-day bio-assay (micronucleus test) and

7 three bio-assays of a longer duration (algal growth, lettuce germination and springtail

8 reproduction, a few days to a few weeks each). This battery of bio-assays could be

9 advised for a cost-effective assessment of contaminated/remediated soils.

\section{Acknowledgements}

The present study was performed with a financial support from the ADEME

14 (Agence de l'Environnement et de la Maîtrise de l'Énergie), which is greatly acknowledged. We thank Total (France) and Charbonnages de France (France) to put at our disposal industrial sites and F. Lecurieux (IPL, France) for his contribution to genotoxicological analyses.

\section{References}

Bispo, A., Jourdain, M.J., Jauzein, M., 1999. Toxicity and genotoxicity of industrial soils polluted by polycyclic aromatic hydrocarbons (PAHs). Organic Geochemistry 30, 947-952.

24 Boularbah, A., Schwartz, C., Bitton, G., Morel, J.L., 2006. Heavy metal contamination from 
mining sites in South Morocco. I. Use of a biotest to assess metal toxicity of tailings and soils. Chemosphere 63, 802-810.

Changchaivong, S., Khaodhiar, S., 2009. Adsorption of naphthalene and phenanthrene on dodecylpyridinum-modified bentonite. Applied Clay Science 43, 317-321.

CTPHT, 2008. Coal-Tar Pitch, High Temperature. Summary risk assessment report. Bureau REACH, Bilthoven.

Degryse, F., Smolders, E., Parker, D.R., 2009. Partitioning of metals (Cd, Co, Cu, Ni, Pb, Zn) in soils: concepts, methodologies, predictions and applications - a review. European Journal of Soil Science 60, 590-612.

Eom, I.C., Rast, C., Veber, A.M., Vasseur, P., 2007. Ecotoxicity of a polycyclic aromatic hydrocarbon (PAH)-contaminated soil. Ecotoxicology and Environmental Safety 67, 190-205.

Gamst, J., Kjeldsen, P., Christensen, T.H., 2007. Determination of solute organic concentration in contaminated soils using a chemical-equilibrium soil column system. Water, Air, and Soil Pollution 183, 377-389.

Hellou, J., 2011. Behavioural ecotoxicology, an "early warning" signal to assess environmental quality. Environmental Science And Pollution Research 18, 1-11.

Hitchcock, P.W., Smith, D.W., 1998. Implications of non-equilibrium sorption on the interception-sorption trench remediation strategy. Geoderma 84, 109-120.

Hoffman, D.J., Rattner, B.A., Burton, G.A. Jr., Cairns, J. Jr., 2002. Handbook of Ecotoxicology, 2nd ed. CRC Press, New York.

ISO, 1993. ISO 11268-1. Soil quality. Effects of pollutants on earthworms (Eisenia fetida). Part 1. Determination of acute toxicity using artificial soil substrate. International Organization for Standardization, Geneva. 
1 ISO, 1996. ISO 6341. Water quality. Determination of the inhibition of the mobility of Daphnia magna Straus (Cladocera, Crustacea). Acute toxicity test. International Organization for Standardization, Geneva.

ISO, 1998a. ISO 11348-3. Water quality. Determination of inhibitory effects of water samples on the light emission of Vibrio fischeri (luminescent bacteria test). Part 3. Method with freeze-dried bacteria. International Organization for Standardization, Geneva.

ISO, 1998b. ISO 13877. Soil quality: determination of polynuclear aromatic hydrocarbons, method using high-performance liquid chromatography. International Organization for Standardization, Geneva.

ISO, 1999. ISO 11267. Soil quality. Inhibition of reproduction of Collembola (Folsomia candida) by soil pollutants. International Organization for Standardization, Geneva.

ISO, 2001. ISO 14869-1. Soil quality. Dissolution for the determination of total element content. Part 1. Dissolution with hydrofluoric and perchloric acids. International Organization for Standardization, Geneva.

ISO, 2002. ISO 14403. Water quality. Determination of total cyanide and free cyanide by continuous flood analysis. International Organization for Standardization, Geneva.

ISO, 2003. ISO 11262. Soil quality. Determination of cyanide. International Organization for Standardization, Geneva.

ISO, 2004. ISO 8692. Water quality. Freshwater algal growth inhibition test with unicellular green algae. International Organization for Standardization, Geneva.

ISO, 2005. ISO 11269-2. Soil quality. Determination of the pollutants effects on soil flora. Part 2. Effects of chemicals on the emergence and growth of higher plants. International Organization for Standardization, Geneva. 
1 ISO, 2007. ISO 21268-2. Soil quality. Leaching procedures for subsequent chemical and ecotoxicological testing of soil and soil materials. Part 2. Batch test using a liquid to solid ratio of $10 \mathrm{l} / \mathrm{kg}$ dry matter. International Organization for Standardization, Geneva.

ISO, 2008a. ISO 20666. Water quality. Determination of the chronic toxicity to Brachionus calyciflorus in 48 h. International Organization for Standardization, Geneva.

ISO, 2008b. ISO 22036. Soil quality. Determination of trace elements in extracts of soil by inductively coupled plasma atomic emission spectrometry (ICP-AES). International Organization for Standardization, Geneva.

Juvonen, R., Martikainen, E., Schulz, E., Joutti, A., Ahtiainen, J., Lehtokari, M., 2000. A battery of toxicity tests as indicators of decontamination in composting oily waste. Ecotoxicology and Environmental Safety 47, 156-166.

Kang, F., Chen, D., Gao, Y., Zhang, Y., 2010. Distribution of polycyclic aromatic hydrocarbons in subcellular root tissues of ryegrass (Lolium multiflorum Lam.). BMC Plant Biology 10:210, doi:10.1186/1471-2229-10-210.

Leaner, J.J., Mason, R.P., 2002. Methylmercury accumulation and fluxes across the intestine of channel catfish, Ictalurus punctatus. Comparative Biochemistry and Physiology, Part C, Toxicology and Pharmacology 132, 247-259.

Leitgib, L., Kalman, J., Gruiz, K., 2007. Comparison of bioassays by testing whole soil and their water extract from contaminated sites. Chemosphere 66, 428-434.

Litchfield, J.T., Wilcoxon, F., 1949. A simplified method of evaluating dose-effect experiments. Journal of Pharmacology 96, 99-113.

Lors, C., Martínez Aldaya, M., Salmon, S., Ponge, J.F., 2006. Use of an avoidance test for the assessment of microbial degradation of PAHs. Soil Biology and Biochemistry 
38, 2199-2204.

2 Lors, C., Ponge, J.F., Martínez Aldaya, M., 2010a. Comparison of solid-phase bioassays and ecoscores to evaluate the toxicity of contaminated soils. Environmental Pollution 158, 2640-2647.

Lors, C., Ryngaert, A., Périé, F., Diels' L., Damidot, D., 2010b. Evolution of bacterial community during bioremediation of PAHs in a coal tar contaminated soil. Chemosphere 81, 1263-1271.

Manzo, S., De Nicola, F., De Luca Picione, F., Maisto, G., Alfani, A., 2008. Assessment of the effects of soil PAH accumulation by a battery of ecotoxicological tests. Chemosphere 71, 1937-1944.

Martínez Aldaya, M., Lors, C., Salmon, S., Ponge, J.P., 2006. Avoidance bio-assays may help to test the ecological significance of soil pollution. Environmental Pollution $140,173-180$.

Maxam, G., Rila, J.P., Dott, W., Eisentraeger, A., 2000. Use of bioassays for assessment of water-extractable ecotoxic potential of soils. Ecotoxicology and Environmental Safety, Section B, Environmental Research 45, 240-246.

Nesslany, F., Marzin, D., 1999. A micromethod for the in vitro micronucleus assay. Mutagenesis 14, 403-410.

Pablos, M.V., Fernández, C., Babín, M., Navas, J.M., Carbonell, G., Martini, F., GarcíaHortigüela, P., Tarazona, J.V., 2009. Use of a novel battery of bioassays for the biological characterisation of hazardous wastes. Ecotoxicology and Environmental Safety $72,1594-1600$.

Pandard, P., Devillers, J., Charissou, A.M., Poulsen, V., Jourdain, M.J., Férard, J.F., Grand, C., Bispo, A., 2006. Selecting a battery of bioassays for ecotoxicological 
Sayer, J.A., Cotter-Howells, J.D., Watson, C., Hillier, S., Gadd, G.M., 1999. Lead mineral transformation by fungi. Current Biology 9, 691-694.

Smolders, E., Oorts, K., Van Sprang, P., Schoeters, I., Janssen, C.R., McGrath, S.P., McLaughlin, M.J., 2009. Toxicity of trace metals in soil as affected by soil type and aging after contamination: using calibrated bioavailability models to set ecological soil standards. Environmental Toxicology and Chemistry 28, 1633-1642.

Sterckeman, T., Douay, F., Proix, N., Fourrier, H., Perdrix, E., 2002. Assessment of the contamination of cultivated soils by eighteen trace elements around smelters in the North of France. Water, Air, and Soil Pollution 135, 173-194.

Van de Wiele, T.R., Verstraete, W., Siciliano, S.D., 2004. Polycyclic aromatic hydrocarbon release from a soil matrix in the in vitro gastrointestinal tract. Journal of Environmental Quality 33, 1343-1353.

Vannier, G., 1987. The porosphere as an ecological medium emphasized in Professor Ghilarov's work on soil animal adaptations. Biology and Fertility of Soils 3, 39-44.

Vasseur, P., Bonnard, M., Palais, F., Eom, I.C., Morel, J.L., 2008. Bioavailability of chemical pollutants in contaminated soils and pitfalls of chemical analyses in hazard assessment. Environmental Toxicology 23, 652-656.

Verschueren, K., 2001. Handbook of Environmental Data on Organic Chemicals, 4th ed. Wiley, New York, NY.

Wicke, D., Böckelmann, U., Reemtsma, T., 2007. Experimental and modeling approach to study sorption of diccolved hydrophobic organic contaminants to microbial biofilms. Water Research 41, 2202-2210. 

and freeze-thawing on extractability of pyrene in soil. Chemosphere 76, 447-452. 


\section{Figure captions}

2

3 Fig. 1. Distribution of PAHs in soil water extracts.

4

5 Fig. 2. Correlation between ecoscores calculated for liquid-phase (abscissa) and solidphase (ordinate) bio-assays. ${ }^{* *}=$ significant at 0.01 level. 1,2 or $3 \mathrm{~T}=$ Soil or Water extract 1, 2 or 3 T according to solid- or liquid-phases, respectively. 
1 Table 1. Characteristics of bioassays used to assess the toxicity of the studied soils and

2 water extracts

\begin{tabular}{|c|c|c|c|c|c|}
\hline Organisms & Contact & $\begin{array}{c}\text { Test } \\
\text { duration }\end{array}$ & Endpoint & $\begin{array}{l}\text { Type of } \\
\text { toxicity }\end{array}$ & $\begin{array}{c}\text { Test } \\
\text { procedure }\end{array}$ \\
\hline $\begin{array}{l}\text { Plants } \\
\text { Lactuca sativa }\end{array}$ & Direct & $14 d$ & $\begin{array}{l}\text { Germination } \\
\text { and growth } \\
\text { inhibition }\end{array}$ & Acute & ISO (2005) \\
\hline $\begin{array}{l}\text { Earthworms } \\
\text { Eisenia fetida }\end{array}$ & Direct & $14 d$ & Survival & Acute & ISO (1993) \\
\hline $\begin{array}{l}\text { Collembola } \\
\text { Folsomia candida }\end{array}$ & Direct & $20 \mathrm{~min}$ & Avoidance & Acute & $\begin{array}{l}\text { Not } \\
\text { standardized }\end{array}$ \\
\hline $\begin{array}{l}\text { Collembola } \\
\text { Folsomia candida }\end{array}$ & Direct & $40 d$ & Reproduction & Chronic & ISO (1999) \\
\hline $\begin{array}{l}\text { Bacteria } \\
\text { Vibrio fischeri } \\
\left(\text { Microtox }^{\circledR}\right)\end{array}$ & Water & $30 \mathrm{~min}$ & $\begin{array}{l}\text { Luminescence } \\
\text { inhibition }\end{array}$ & Acute & ISO (1998) \\
\hline $\begin{array}{l}\text { Micro-crustaceans } \\
\text { Daphnia magna }\end{array}$ & Water & $48 \mathrm{~h}$ & Immobilization & Acute & ISO (1996) \\
\hline $\begin{array}{l}\text { Algae } \\
\text { Pseudokirchneriella } \\
\text { subcapitata }\end{array}$ & Water & $72 \mathrm{~h}$ & $\begin{array}{l}\text { Growth } \\
\text { inhibition }\end{array}$ & Chronic & ISO (2004) \\
\hline $\begin{array}{l}\text { Rotifers } \\
\text { Brachionus } \\
\text { calyciflorus }\end{array}$ & Water & $48 \mathrm{~h}$ & $\begin{array}{l}\text { Growth } \\
\text { inhibition }\end{array}$ & Chronic & ISO (2008) \\
\hline $\begin{array}{l}\text { Animals } \\
\text { Mouse lymphoma } \\
\text { cells }\end{array}$ & Water & $24 \mathrm{~h}$ & $\begin{array}{l}\text { Chromosomic } \\
\text { change }\end{array}$ & Genotoxicity & $\begin{array}{l}\text { Not } \\
\text { standardized }\end{array}$ \\
\hline
\end{tabular}


1 Table 2. Concentrations of $16 \mathrm{PAHs}$, cyanides and heavy metals in tested soils

2 (expressed in $\mathrm{mg} \mathrm{kg}^{-1}$ dry soil $\pm \mathrm{SE}$ ), compared with the geochemical background, i.e.

3 concentrations measured over a wide range of unpolluted agricultural and forest soils

4 (Sterckeman et al., 2002) and with Predicted No Effect Concentrations (PNEC) on various

5 terrestrial organisms, according to CTPHT (2008) for PAH and Smolders et al. (2009) for

6 trace metals

\begin{tabular}{|c|c|c|c|c|c|c|}
\hline & Soil 1 & Soil 2 & Soil 3 & Soil 3T & $\begin{array}{l}\text { Geochemical } \\
\text { background }\end{array}$ & PNEC \\
\hline Naphthalene & $19.2 \pm 0.7$ & $150.9 \pm 10.6$ & $594.2 \pm 13.8$ & $11.1 \pm 4.9$ & & 1.0 \\
\hline Acenaphthylene & $1.9 \pm 0.04$ & $23.5 \pm 1.1$ & $3.1 \pm 0.1$ & $0.2 \pm 0.4$ & & 0.29 \\
\hline Acenaphthene & $1.9 \pm 0.04$ & $2 \pm 0.1$ & $217.4 \pm 1.2$ & $7.4 \pm 0.6$ & & 0.038 \\
\hline Fluorene & $19.3 \pm 0.3$ & $83.1 \pm 3.7$ & $226.8 \pm 2.8$ & $4.5 \pm 4.2$ & & 1.0 \\
\hline Phenanthrene & $119.4 \pm 17.7$ & $308.2 \pm 17.7$ & $629.3 \pm 4.2$ & $3.8 \pm 0.8$ & & 1.8 \\
\hline Anthracene & $183.2 \pm 8.3$ & $206.7 \pm 7$ & $202.5 \pm 31.7$ & $19.1 \pm 5.9$ & & 0.13 \\
\hline Fluoranthene & $130.8 \pm 22.5$ & $625.2 \pm 30.7$ & $414.3 \pm 1.2$ & $55.1 \pm 11.9$ & & 1.5 \\
\hline Pyrene & $54.5 \pm 9.9$ & $299.4 \pm 10.9$ & $233.4 \pm 0.4$ & $50.6 \pm 9.9$ & & 1.0 \\
\hline Benzo[a]anthracene & $48.4 \pm 9.2$ & $391.9 \pm 13.1$ & $85.7 \pm 0.9$ & $21.2 \pm 2.9$ & & 0.079 \\
\hline Chrysene & $47.7 \pm 8.2$ & $410.4 \pm 8.1$ & $75.4 \pm 0.9$ & $19.0 \pm 2.7$ & & 0.55 \\
\hline Benzo[b]anthracene & $2.6 \pm 1$ & $210.8 \pm 5.8$ & $56.2 \pm 0.3$ & $42.9 \pm 5.4$ & & 0.27 \\
\hline Benzo[k]fluoranthene & $2.8 \pm 0.8$ & $161.9 \pm 2.6$ & $25.8 \pm 0.3$ & $15.7 \pm 1.7$ & & 0.27 \\
\hline Benzo[a]pyrene & $38.2 \pm 2.6$ & $364.1 \pm 2.9$ & $60.4 \pm 6.7$ & $37.1 \pm 4.8$ & & 0.053 \\
\hline Dibenzo[ah]anthracene & $4.9 \pm 0.5$ & $59.3 \pm 0.3$ & $6.9 \pm 0.2$ & $1.4 \pm 0.1$ & & 0.054 \\
\hline Benzo[ghi]perylene & $15.1 \pm 1.5$ & $196.1 \pm 6.5$ & $32.5 \pm 1$ & $21.4 \pm 4.2$ & & 0.17 \\
\hline 2-ring PAH & $19.2 \pm 0.4$ & $150.9 \pm 6.1$ & $594.2 \pm 8$ & $11.1 \pm 1$ & & \\
\hline 3-ring PAHs & $325.7 \pm 15.1$ & $623.5 \pm 17.1$ & $1279.2 \pm 20.3$ & $35 \pm 5.7$ & & \\
\hline 4-ring PAHs & $281.3 \pm 28.8$ & $1726.9 \pm 36.2$ & $808.9 \pm 1$ & $145.9 \pm 15.8$ & & \\
\hline 5-ring PAHs & $48.6 \square 2.8$ & $796.1 \pm 6.7$ & $149.2 \pm 3.7$ & $97.2 \pm 6.9$ & & \\
\hline 6-ring PAHs & $26.3 \pm 1.4$ & $389.8 \pm 4.6$ & $63.2 \pm 0.4$ & $56.2 \pm 5.4$ & & \\
\hline$\sum 16$ PAHs & $701.2 \pm 48.6$ & $3687.2 \pm 48.8$ & $2894.8 \pm 38.1$ & $345.4 \pm 23.4$ & & \\
\hline $\mathrm{CN}^{-}$ & 6.6 & 67 & 0.8 & 0.5 & & \\
\hline As & $21.7 \pm 0.9$ & $33.4 \pm 1.5$ & $6.5 \pm 0.3$ & $6.5 \pm 0.5$ & $8.9 \pm 0.7$ & \\
\hline Cd & $<4$ & $5.2 \pm 0.01$ & $<4$ & $<4$ & $0.4 \pm 0.02$ & 1.1 \\
\hline Co & $8.0 \pm 0.06$ & $48.9 \pm 0.8$ & $9.6 \pm 0.1$ & $8.9 \pm 0.06$ & $9.3 \pm 0.5$ & \\
\hline $\mathrm{Cr}$ & $31.9 \pm 0.4$ & $52.2 \pm 2.3$ & $32.9 \pm 0.2$ & $31.3 \pm 0.5$ & $48.8 \pm 1.6$ & \\
\hline $\mathrm{Cu}$ & $47.8 \pm 2.2$ & $126.4 \pm 0.2$ & $19.3 \pm 0.2$ & $21.0 \pm 0.3$ & $16.7 \pm 1$ & 33.8 \\
\hline $\mathrm{Ni}$ & $21.1 \pm 0.2$ & $46.9 \pm 1.1$ & $19.8 \pm 0.1$ & $26.8 \pm 1.9$ & $24.7 \pm 3.3$ & 13.8 \\
\hline $\mathrm{Pb}$ & $35.1 \pm 2.2$ & $345.7 \pm 4$ & $23.9 \pm 0.5$ & $25.9 \pm 2.1$ & $38.4 \pm 3.2$ & 167.9 \\
\hline $\mathrm{Zn}$ & $75.1 \pm 6.9$ & $514.0 \pm 6.1$ & $92.7 \pm 0.5$ & $104 \pm 3.3$ & $73.7 \pm 3.6$ & 81.9 \\
\hline
\end{tabular}


1 Table 3. Concentration ( $\left.\mu \mathrm{g} \mathrm{I}^{-1}\right)$ of PAHs in water extracts of studied soils (mean $\pm \mathrm{SE}$ )

2 compared with Predicted No Effect Concentrations (PNEC) on various fresh water

3 organisms, according to CTPHT (2008)

\begin{tabular}{|c|c|c|c|c|c|}
\hline & $\begin{array}{l}\text { Water } \\
\text { extract } 1\end{array}$ & $\begin{array}{l}\text { Water } \\
\text { extract } 2\end{array}$ & $\begin{array}{l}\text { Water } \\
\text { extract } 3\end{array}$ & $\begin{array}{l}\text { Water } \\
\text { extract 3T }\end{array}$ & PNEC \\
\hline Naphthalene & $0.09 \pm 0.02$ & $0.62 \pm 0.18$ & $0.20 \pm 0.02$ & $0.28 \pm 0.02$ & 2.0 \\
\hline Acenaphthene & $0.09 \pm 0.01$ & $0.62 \pm 0.07$ & $154.1 \pm 1.5$ & $1.03 \pm 0.03$ & 3.8 \\
\hline Fluorene & $0.11 \pm 0.02$ & $0.72 \pm 0.14$ & $198.7 \pm 3.7$ & $0.82 \pm 0.03$ & 2.5 \\
\hline Phenanthrene & $0.19 \pm 0.02$ & $1.37 \pm 0.2$ & $151.4 \pm 2.8$ & $1.63 \pm 0.1$ & 1.3 \\
\hline Anthracene & $0.66 \pm 0.04$ & $1.34 \pm 0.3$ & $26.91 \pm 0.36$ & $1.20 \pm 0.1$ & 0.1 \\
\hline Fluoranthene & $0.14 \pm 0.02$ & $4.05 \pm 0.72$ & $51.2 \pm 0.9$ & $20.7 \pm 0.6$ & 0.01 \\
\hline Pyrene & $1.18 \pm 0.1$ & $3.11 \pm 0.58$ & $28.9 \pm 0.5$ & $23.8 \pm 0.9$ & 0.023 \\
\hline Benzo(a)antracene & $0.08 \pm 0.03$ & $3.11 \pm 0.56$ & $7.97 \pm 0.14$ & $7.86 \pm 0.26$ & 0.012 \\
\hline Chrysene & $0.13 \pm 0.03$ & $3.43 \pm 0.55$ & $8.78 \pm 0.12$ & $3.98 \pm 0.13$ & 0.07 \\
\hline Benzo(b)fluoranthene & $0.31 \pm 0.05$ & $8.42 \pm 1.44$ & $3.85 \pm 0.05$ & $10.57 \pm 0.4$ & 0.017 \\
\hline Benzo(k)fluoranthene & $0.13 \pm 0.02$ & $2.71 \pm 0.46$ & $2.30 \pm 0.03$ & $5.48 \pm 0.21$ & 0.017 \\
\hline Benzo(a)pyrene & $0.33 \pm 0.05$ & $6.86 \pm 1.37$ & $4.41 \pm 0.02$ & $10.79 \pm 0.43$ & 0.022 \\
\hline Dibenzo(a,h)anthracene & $0.14 \pm 0.01$ & $3.43 \pm 0.56$ & $0.72 \pm 0.01$ & $1.22 \pm 0.05$ & 0.0014 \\
\hline Benzo(g,h,i)perylene & $0.18 \pm 0.02$ & $8.42 \pm 1.70$ & $3.00 \pm 0.03$ & $6.39 \pm 0.27$ & 0.0082 \\
\hline Indeno(1,2,3)pyrene & $0.21 \pm 0.02$ & $9.04 \pm 1.77$ & $2.30 \pm 0.02$ & $4.06 \pm 0.17$ & 0.0027 \\
\hline 2-ring PAHs & $0.09 \pm 0.02$ & $0.62 \pm 0.18$ & $0.20 \pm 0.02$ & $0.28 \pm 0.02$ & \\
\hline 3-ring PAHs & $1.05 \pm 0.09$ & $4.05 \pm 0.72$ & $531.1 \pm 8.3$ & $4.68 \pm 0.27$ & \\
\hline 4-ring PAHs & $1.53 \pm 0.19$ & $13.7 \pm 2.4$ & $96.9 \pm 1.7$ & $56.3 \pm 1.9$ & \\
\hline 5-ring PAHs & $0.91 \pm 0.13$ & $21.4 \pm 3.8$ & $11.3 \pm 0.1$ & $28.06 \pm 1.09$ & \\
\hline 6-ring PAHs & $0.39 \pm 0.03$ & $17.5 \pm 3.5$ & $5.30 \pm 0.05$ & $10.45 \pm 0.44$ & \\
\hline$\Sigma 16-\mathrm{PAHs}$ & $3.97 \pm 0.46$ & $57.3 \pm 11$ & $645 \pm 12$ & $99.7 \pm 3.6$ & \\
\hline
\end{tabular}


1 Table 4. PAH water extraction capacity in water extracts of studied soils expressed by the 2 ratio $\mathrm{PAH}$ concentration in water extract/soil $\left(\mathrm{mg} \mathrm{l}^{-1} / \mathrm{mg} \mathrm{kg}^{-1}\right)$

Water extract 1 Water extract 2 Water extract 3 Water extract 3T

\begin{tabular}{lllll}
\hline 2-ring PAHs & $4.710^{-6}$ & $4.110^{-6}$ & $3.410^{-7}$ & $2.510^{-5}$ \\
3-ring PAHs & $3.210^{-6}$ & $6.510^{-6}$ & $4.210^{-4}$ & $1.310^{-4}$ \\
4-ring PAHs & $5.410^{-6}$ & $7.910^{-6}$ & $1.210^{-4}$ & $3.910^{-4}$ \\
5-ring PAHs & $1.910^{-5}$ & $2.710^{-5}$ & $7.610^{-5}$ & $2.910^{-4}$ \\
6-ring PAHs & $1.510^{-5}$ & $4.510^{-5}$ & $8.410^{-5}$ & $1.910^{-4}$ \\
$\sum$ 16 PAHs & $5.710^{-6}$ & $1.610^{-5}$ & $2.210^{-4}$ & $2.910^{-4}$ \\
\hline
\end{tabular}


1 Table 5. Toxicity of Soil 1 according to the battery of solid and liquid bioassays

\begin{tabular}{|c|c|c|c|c|c|c|c|}
\hline & $\begin{array}{c}E_{50} \\
\left(\mathrm{~g} .100 \mathrm{~g}^{-1}\right)\end{array}$ & $\begin{array}{c}\text { TU } \\
100 / \mathrm{EC}_{50}\end{array}$ & $\begin{array}{c}E_{20} \\
\left(\mathrm{~g} .100 \mathrm{~g}^{-1}\right)\end{array}$ & $\begin{array}{c}\text { EC }_{10} \\
\left(\mathrm{~g} .100 \mathrm{~g}^{-1}\right)\end{array}$ & $\begin{array}{c}\text { NOEC } \\
\left(\mathrm{g} .100 \mathrm{~g}^{-1}\right)\end{array}$ & $\begin{array}{c}\text { Inhibition } \\
(\%)\end{array}$ & $\begin{array}{c}\text { Ecoscore } \\
(\%)\end{array}$ \\
\hline Lactuca germination & $>100$ & $<1$ & $\begin{array}{c}64.9 \\
(48.9-86.2)\end{array}$ & $\begin{array}{c}25.3 \\
(13.5-47.5)\end{array}$ & $<35$ & 20.4 & 47 \\
\hline Lactuca growth inhibition & $>100$ & $<1$ & $>100$ & $\begin{array}{c}87.4 \\
(72.5->100)\end{array}$ & 100 & 0.7 & 13 \\
\hline Eisenia mortality & NT & NT & NT & NT & NT & 0 & 0 \\
\hline Folsomia population growth & $\begin{array}{c}93.5 \\
(75.3->100)\end{array}$ & 1.1 & $\begin{array}{c}37.0 \\
(30.0-45.7)\end{array}$ & $\begin{array}{c}22.8 \\
(17.2-30.3)\end{array}$ & 10 & 63.6 & 60 \\
\hline Folsomia avoidance & $\begin{array}{c}27.1 \\
(19.5-37.6)\end{array}$ & 3.7 & $\begin{array}{c}2.9 \\
(2.0-4.3)\end{array}$ & $\begin{array}{c}0.9 \\
(0.5-1.6)\end{array}$ & $<0.35$ & 9.5 & 80 \\
\hline Microtox ${ }^{\circledR}$ test & $>100$ & $<1$ & $\begin{array}{c}52.7 \\
(39.5-70.2)\end{array}$ & $\begin{array}{c}23.1 \\
(17.0-31.3)\end{array}$ & $<6.25$ & 32.7 & 53 \\
\hline Daphnia mobility & NT & NT & NT & NT & NT & 0 & 0 \\
\hline Algal growth & $\begin{array}{c}92.5 \\
(80.4->100)\end{array}$ & 1.1 & $\begin{array}{c}55.5 \\
(49.4-62.4)\end{array}$ & $\begin{array}{c}42.5 \\
(36.2-49.9)\end{array}$ & 25 & 47.4 & 53 \\
\hline Rotifer growth & NT & NT & NT & NT & NT & 0 & 0 \\
\hline Micronucleus test (-S9) & NM & NM & NM & NM & NM & $\mathrm{N} / \mathrm{A}$ & 0 \\
\hline
\end{tabular}

$2 \mathrm{EC}_{50}, \mathrm{EC}_{20}, \mathrm{EC}_{10}=$ concentration causing $50 \%, 20 \%, 10 \%$ inhibition of germination rate,

3 respectively (confidence interval at 0.05 risk level between brackets); $T U=100 / E C_{50} ; \mathrm{NOEC}=$ no

4 observed effect concentration; NT = not toxic, observed response statistically indistinguishable from

5 unpolluted soil sampled on the studied site; $N M=$ not mutagenic; N/A = not applicable; inhibition

$6 \quad(\%)=$ relative decrease in response compared to control soil at the highest dose tested 
1 Table 6. Toxicity of Soil 2 according to the battery of solid and liquid bioassays. Otherwise

2 as for Table 5

\begin{tabular}{|c|c|c|c|c|c|c|c|}
\hline & $\begin{array}{c}\text { EC }_{50} \\
\left(\mathrm{~g} .100 \mathrm{~g}^{-1}\right)\end{array}$ & $\begin{array}{c}\text { TU } \\
100 / \mathrm{EC}_{50}\end{array}$ & $\begin{array}{c}E_{20} \\
\left(\mathrm{~g} .100 \mathrm{~g}^{-1}\right)\end{array}$ & $\begin{array}{c}E_{10} \\
\left(\mathrm{~g} .100 \mathrm{~g}^{-1}\right)\end{array}$ & $\begin{array}{c}\text { NOEC } \\
\left(\mathrm{g} .100 \mathrm{~g}^{-1}\right)\end{array}$ & $\begin{array}{c}\text { Inhibition } \\
(\%)\end{array}$ & $\begin{array}{c}\text { Ecoscore } \\
(\%)\end{array}$ \\
\hline Lactuca germination & $>100$ & $<1$ & $\begin{array}{c}80.8 \\
(62.9->100)\end{array}$ & $\begin{array}{c}41.7 \\
(29.9-58.1)\end{array}$ & $<35$ & 21.4 & 47 \\
\hline Lactuca growth inhibition & $>100$ & $<1$ & $>100$ & $\begin{array}{c}95.1 \\
(83.5->100)\end{array}$ & 60 & 10 & 20 \\
\hline Eisenia mortality & $\begin{array}{c}>100 \\
(97.8->100)\end{array}$ & $<1$ & $\begin{array}{c}88.0 \\
(83.0-93.2)\end{array}$ & $\begin{array}{c}79.1 \\
(72.2-86.7)\end{array}$ & 60 & 37.5 & 33 \\
\hline Folsomia population growth & NT & NT & NT & NT & NT & 0 & 0 \\
\hline Folsomia avoidance & $>100$ & $<1$ & $\begin{array}{c}1.7 \\
(0.6-5.1)\end{array}$ & $\begin{array}{c}0.04 \\
(0.004-0.403)\end{array}$ & $<0.35$ & 12.5 & 67 \\
\hline Microtox test & NT & NT & NT & NT & NT & 0 & 0 \\
\hline Daphnia mobility & NT & NT & NT & NT & NT & 0 & 0 \\
\hline Algal growth & $\begin{array}{c}80.5 \\
(51.7->100)\end{array}$ & 1.2 & $\begin{array}{c}8.4 \\
(5.3-13.5)\end{array}$ & $\begin{array}{c}2.6 \\
(1.2-5.7)\end{array}$ & $<6.25$ & 56.5 & 80 \\
\hline Rotifer growth & $>100$ & $<1$ & $\begin{array}{c}30.2 \\
(18.6-49.1)\end{array}$ & $\begin{array}{c}4.6 \\
(1.7-12.4)\end{array}$ & $<6.25$ & 32.1 & 67 \\
\hline Micronucleus test (-S9) & NM & NM & NM & NM & NM & $N / A$ & 0 \\
\hline
\end{tabular}

3

4 
1 Table 7. Toxicity of Soil 3 according to the battery of solid and liquid bioassays. Otherwise

2 as for Table 5

\begin{tabular}{|c|c|c|c|c|c|c|c|}
\hline & $\begin{array}{c}E_{50} \\
\left(\mathrm{~g} .100 \mathrm{~g}^{-1}\right) \\
\end{array}$ & $\begin{array}{c}\text { TU } \\
100 / \mathrm{EC}_{50}\end{array}$ & $\begin{array}{c}E_{20} \\
\left(\mathrm{~g} .100 \mathrm{~g}^{-1}\right)\end{array}$ & $\begin{array}{c}E C_{10} \\
\left(\mathrm{~g} .100 \mathrm{~g}^{-1}\right)\end{array}$ & $\begin{array}{c}\text { NOEC } \\
\left(\mathrm{g} .100 \mathrm{~g}^{-1}\right)\end{array}$ & $\begin{array}{c}\text { Inhibition } \\
(\%)\end{array}$ & $\begin{array}{c}\text { Ecoscore } \\
(\%)\end{array}$ \\
\hline Lactuca germination & $\begin{array}{c}21.3 \\
(15.5-29.3)\end{array}$ & 4.5 & $\begin{array}{c}3.5 \\
(1.9-6.5)\end{array}$ & $\begin{array}{c}1.4 \\
(0.6-3.4)\end{array}$ & $<5$ & 70.9 & 93 \\
\hline Lactuca growth inhibition & $\begin{array}{c}16.6 \\
(13.1-21.0)\end{array}$ & 5.8 & $\begin{array}{c}2.9 \\
(1.7-4.8)\end{array}$ & $\begin{array}{c}1.2 \\
(0.6-2.4)\end{array}$ & $<5$ & 79.3 & 93 \\
\hline Eisenia mortality & $\begin{array}{c}0.60 \\
(0.56-0.64)\end{array}$ & 167 & $\begin{array}{c}0.51 \\
(0.46-0.55)\end{array}$ & $\begin{array}{c}0.46 \\
(0.41-0.51)\end{array}$ & 0.4 & 100 & 100 \\
\hline Folsomia population growth & $\begin{array}{l}2.2 \\
\mathrm{~N} / \mathrm{A}\end{array}$ & 45.5 & $\begin{array}{l}2.1 \\
N / A\end{array}$ & $\begin{array}{r}1.9 \\
\text { N/A }\end{array}$ & 1 & 100 & 100 \\
\hline Folsomia avoidance & $\begin{array}{c}0.8 \\
(0.6-1)\end{array}$ & 129 & $\begin{array}{c}0.3 \\
(0.2-0.4)\end{array}$ & $\begin{array}{c}0.042 \\
(0.008-0.205)\end{array}$ & $<0.35$ & 100 & 100 \\
\hline Microtox test & $\begin{array}{c}8.1 \\
(6.4-10.1)\end{array}$ & 12.4 & $\begin{array}{c}1.5 \\
(0.9-2.3)\end{array}$ & $\begin{array}{c}0.6 \\
(0.3-1.1)\end{array}$ & $<2.5$ & 89.1 & 100 \\
\hline Daphnia mobility & $\begin{array}{l}50.0 \\
N / A\end{array}$ & 2.0 & $\begin{array}{l}50.0 \\
\mathrm{~N} / \mathrm{A}\end{array}$ & $\begin{array}{l}50.0 \\
N / A\end{array}$ & 25 & 100 & 73 \\
\hline Algal growth & $\begin{array}{c}42.9 \\
(40.4-45.6)\end{array}$ & 2.3 & $\begin{array}{c}28.0 \\
(25.7-30.5)\end{array}$ & $\begin{array}{c}22.4 \\
(20.0-25.0)\end{array}$ & $<20$ & 93.4 & 80 \\
\hline Rotifer growth & $\begin{array}{c}77.2 \\
(58.1->100)\end{array}$ & 1.3 & $\begin{array}{c}19.1 \\
(15.1-24.1)\end{array}$ & $\begin{array}{c}9.2 \\
(6.5-13.0)\end{array}$ & $<6.25$ & 57.7 & 80 \\
\hline Micronucleus test (-S9) & $\begin{array}{c}16.1 \\
(13.4-19.3)\end{array}$ & 6.2 & $\begin{array}{c}6.8 \\
(5.0-9.4)\end{array}$ & $\begin{array}{c}4.4 \\
(2.9-6.5)\end{array}$ & $<12.5$ & $\mathrm{~N} / \mathrm{A}$ & 80 \\
\hline
\end{tabular}

3

4 
1 Table 8. Toxicity of Soil 3T according to the battery of solid and liquid bioassays.

2 Otherwise as for Table 5

\begin{tabular}{|c|c|c|c|c|c|c|c|}
\hline & $\begin{array}{c}E_{50} \\
\left(\mathrm{~g} .100 \mathrm{~g}^{-1}\right)\end{array}$ & $\begin{array}{c}\text { TU } \\
100 / \mathrm{EC}_{50}\end{array}$ & $\begin{array}{c}E_{20} \\
\left(\mathrm{~g} .100 \mathrm{~g}^{-1}\right)\end{array}$ & $\begin{array}{c}E_{C_{10}} \\
\left(\mathrm{~g} .100 \mathrm{~g}^{-1}\right)\end{array}$ & $\begin{array}{c}\text { NOEC } \\
\left(\mathrm{g} .100 \mathrm{~g}^{-1}\right)\end{array}$ & $\begin{array}{c}\text { Inhibition } \\
(\%)\end{array}$ & $\begin{array}{c}\text { Ecoscore } \\
(\%)\end{array}$ \\
\hline Lactuca germination & NT & NT & NT & NT & NT & 0 & 0 \\
\hline Lactuca growth inhibition & NT & NT & NT & NT & NT & 0 & 0 \\
\hline Eisenia mortality & NT & NT & NT & NT & NT & 0 & 0 \\
\hline Folsomia population growth & $>100$ & $<1$ & $>100$ & $\begin{array}{c}5.2 \\
(1.8-15.1)\end{array}$ & $<0.35$ & 27 & 53 \\
\hline Folsomia avoidance & NA & NA & NA & NA & NA & 0 & 0 \\
\hline Microtox test & $\mathrm{N} / \mathrm{A}$ & $\mathrm{N} / \mathrm{A}$ & $\mathrm{N} / \mathrm{A}$ & $\mathrm{N} / \mathrm{A}$ & $\mathrm{N} / \mathrm{A}$ & 26.7 & 13 \\
\hline Daphnia mobility & NT & NT & NT & NT & NT & 0 & 0 \\
\hline Algal growth & $>100$ & $<1$ & $\begin{array}{c}39.1 \\
(32.5-47.1)\end{array}$ & $\begin{array}{c}21.1 \\
(16.3-27.3)\end{array}$ & $<10$ & 43.2 & 60 \\
\hline Rotifer growth & NT & NT & NT & NT & NT & 0 & 0 \\
\hline Micronucleus test (-S9) & NT & NT & NT & NT & NT & $\mathrm{N} / \mathrm{A}$ & 0 \\
\hline
\end{tabular}

3

4 
1 Table 9. Ecoscores of the four studied soils obtained with five solid-phase bioassays and

2 five liquid-phase bioassays. Total ecoscores are average values of the ten tested

3 bioassays (rows) or of the four soils (columns).

\begin{tabular}{|c|c|c|c|c|c|c|c|c|c|c|c|c|}
\hline & $\begin{array}{c}\text { Lactuca } \\
\text { germination } \\
(*)\end{array}$ & $\begin{array}{c}\text { Lactuca } \\
\text { Growth } \\
\text { inhibition }\end{array}$ & $\begin{array}{c}\text { Eisenia } \\
\text { mortality }\end{array}$ & $\begin{array}{c}\text { Folsomia } \\
\text { Population } \\
\text { growth } \\
\left(^{*}\right)\end{array}$ & $\begin{array}{c}\text { Folsomia } \\
\text { avoidance } \\
\left({ }^{*}\right)\end{array}$ & $\begin{array}{c}\text { Microtox } \\
\text { test } \\
(*)\end{array}$ & $\begin{array}{l}\text { Daphnia } \\
\text { mobility }\end{array}$ & $\begin{array}{c}\text { Algal } \\
\text { growth } \\
\left({ }^{*}\right)\end{array}$ & $\begin{array}{l}\text { Brachionus } \\
\text { growth }\end{array}$ & $\begin{array}{l}\text { Micro- } \\
\text { Nucleus } \\
\text { test ( }\left(^{*}\right)\end{array}$ & Total & $\begin{array}{c}\text { Total } \\
\text { reduced } \\
\text { battery } \\
\left(^{*}\right)\end{array}$ \\
\hline Soil 1 & 47 & 13 & 0 & 60 & 80 & 53 & 0 & 53 & 0 & 0 & 31 & 59 \\
\hline Soil 2 & 47 & 20 & 33 & 0 & 67 & 0 & 0 & 80 & 67 & 0 & 31 & 39 \\
\hline Soil 3 & 93 & 93 & 100 & 100 & 100 & 100 & 73 & 80 & 80 & 80 & 82 & 95 \\
\hline Soil 3T & 0 & 0 & 0 & 53 & 0 & 13 & 0 & 60 & 0 & 0 & 13 & 25 \\
\hline Total & 47 & 32 & 33 & 53 & 62 & 42 & 18 & 68 & 37 & 20 & & \\
\hline
\end{tabular}

$4 \quad\left(^{*}\right)$ tests selected for the reduced test battery

5 


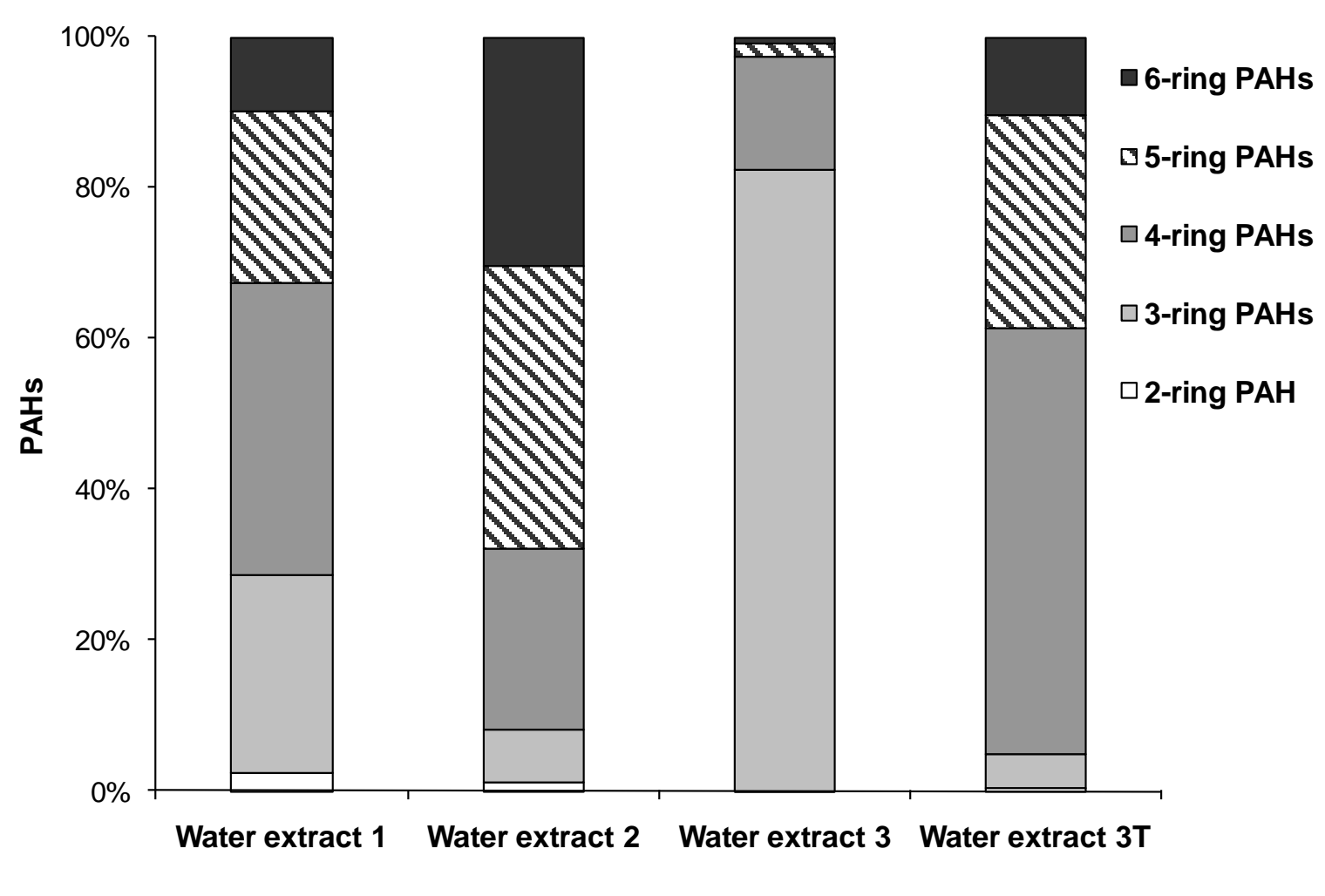

2 Fig. 1 


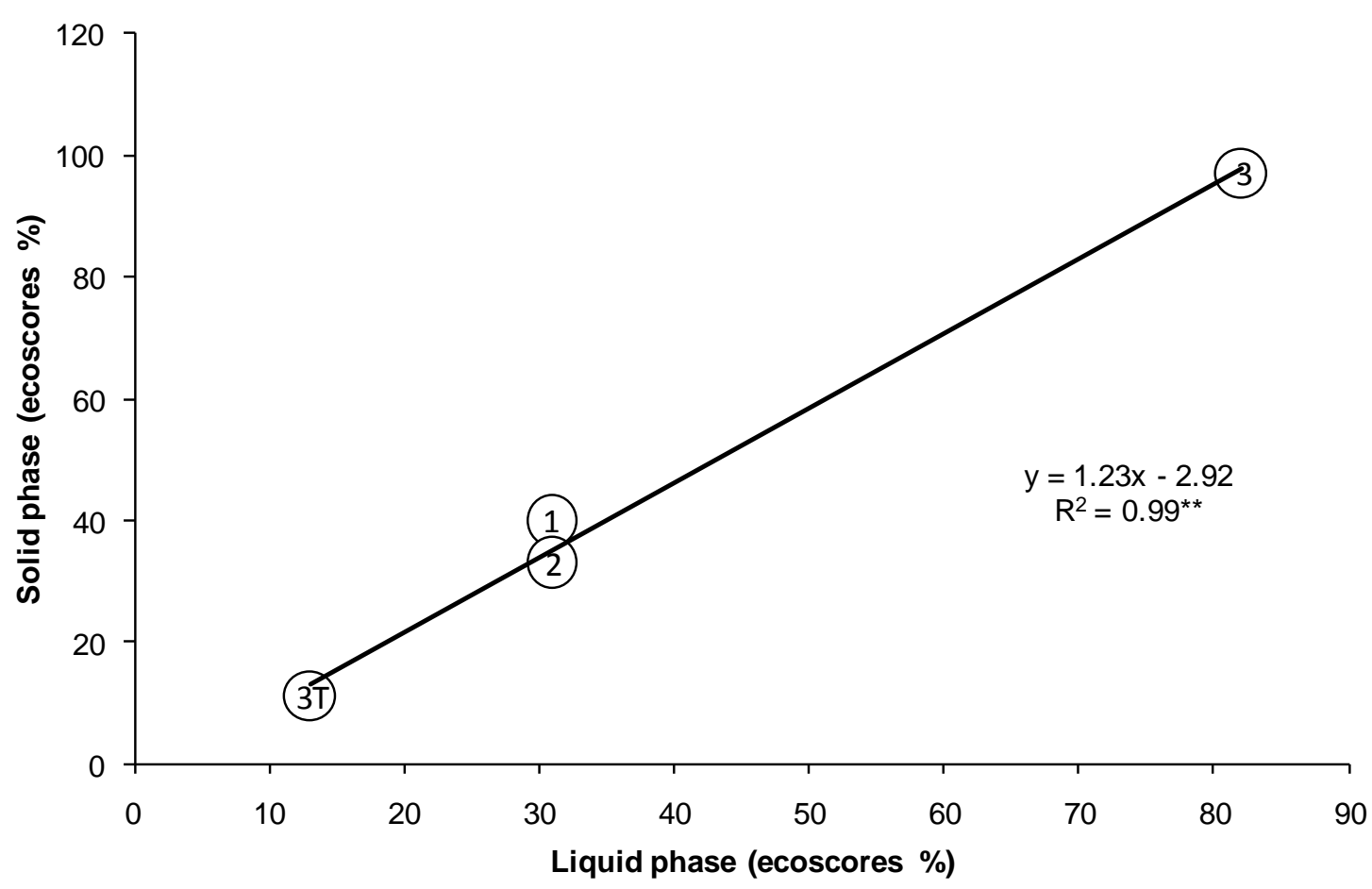

2 Fig. 2 